\title{
FIFA, Forced Arbitration, and the U.S. Soccer Lawsuits
}

\begin{abstract}
Steven A. Bank*
American soccer has been besieged by lawsuits. In the last two years alone, the United States Soccer Federation ("U.S. Soccer") has been hit with two antitrust lawsuits, two Equal Pay Act and Title VII gender discrimination lawsuits, and a trademark lawsuit, while two of its professional league members are engaged in their own trademark lawsuit. One threshold question that has received scant attention in the media is whether these disputes should be in federal court at all. Under the Statutes and Regulations of the Fédération Internationale de Football Association ("FIFA"), soccer's global governing organization, all disputes are required to be arbitrated. Taking a dispute to an ordinary court of law is potentially subject to sanction, which could include suspension or even expulsion. Given this forced arbitration rule, this article considers several possible explanations for why there has been no push to arbitrate the disputes in most of the lawsuits: (1) The enforceability of FIFA's arbitration requirement has been called into question by recent rulings against forced arbitration clauses; (2) FIFA focuses the enforcement of its arbitration requirement on certain types of cases; (3) FIFA does not consider certain types of claims subject to arbitration; and (4) U.S. Soccer's bylaws do not impose the arbitration requirement in such a way as it would apply to these types of cases. Although none of these entirely resolve the matter in a satisfactory way, in the aggregate they may help to define the emerging limits to arbitration for sports governing bodies in the U.S. and elsewhere.
\end{abstract}

Keywords: arbitration, antitrust, Equal Pay Act, Title VII, trademark, soccer, FIFA

\section{Introduction}

American soccer has been besieged by lawsuits in the last few years. In September of 2017, the North American Soccer League ("NASL") filed an antitrust lawsuit against the United States Soccer Federation ("U.S. Soccer") in federal court, alleging that USSF conspired with Major League Soccer ("MLS") to erect and arbitrarily apply a shifting set of divisional sanctioning requirements that prevented NASL from challenging MLS for supremacy in U.S. soccer. ${ }^{1}$ A little over a year later, in December of 2018, the U.S. Soccer

\footnotetext{
Complaint, N. Am. Soccer League, LLC v. U.S. Soccer Fed'n, Inc., No. 1:17-cv-05495 (E.D.N.Y. filed Sept. 19, 2017).

* Steven A. Bank, JD, is the Vice Dean for Curricular and Academic Affairs and the Paul Hastings Professor of Business Law, UCLA School of Law; email: bank@1aw.ucla.edu. He wishes to thank Jackson Sullivan for research assistance and Camille Comte for translation assistance.
} 
Foundation sued U.S. Soccer in federal court, seeking a declaratory judgment that would allow it to continue to use its trademarks, which had originally been filed and owned by U.S. Soccer. ${ }^{2}$ At that point, the lawsuits started to come in rapid succession. In March of 2019, the U.S. Women's National Team players sued U.S. Soccer for gender discrimination and violations of the Equal Pay Act, ${ }^{3}$ a claim also brought in a separate lawsuit by former U.S. Women's National Team goalkeeper Hope Solo against U.S. Soccer in August of 2018. In May of 2019, the United Soccer Leagues ("USL") filed its own trademark lawsuit against the United Premier Soccer League ("UPSL"), alleging that UPSL had used USL's trademarks or marks confusingly similar to USL's marks. ${ }^{4}$ Finally, in September of 2019, Relevent Sports ("Relevent"), a company that promotes international soccer matches, filed an antitrust complaint against U.S. Soccer for its refusal to sanction international league matches held within the U.S. ${ }^{5}$ Relevent originally filed the lawsuit in New York state court in April 2019, but ended up withdrawing the case and re-filing it in federal court as an antitrust case with broader claims. ${ }^{6}$

One threshold question that has received scant attention in the media is whether these disputes should be in federal court at all. Under the Statutes and Regulations of the Fédération Internationale de Football Association ("FIFA"), soccer's global governing organization, simply taking a dispute to an outside court is potentially a violation of FIFA rules. Article 59(2) of the FIFA Statutes provides that "recourse to ordinary courts of law is prohibited unless specifically provided for in the FIFA regulations." Article 59(3) then directs national associations to insert a clause in their own statutes or regulations prohibiting members "to take disputes ... to ordinary courts of law" unless recourse to ordinary courts is specifically provided for under FIFA regulations or "binding legal provisions." 8 It states that "instead of recourse to ordinary courts of law, provision shall be made for arbitration." It commands national associations to "impose sanctions on any party that fails to respect this obligation."10

Given this forced arbitration rule, why are so many of these lawsuits, each of which involves U.S. Soccer, members of U.S. Soccer, or registered agents of FIFA, in federal court rather than before an arbitration panel? With one

\footnotetext{
2 Complaint, U.S. Soccer Fed'n Found., Inc. v. U.S. Soccer Fed'n, Inc., No. 1:18-cv-02856 (D.D.C. filed Dec. 06, 2018).

3 Complaint, Solo v. U.S. Soccer Fed'n, No. 3:18-cv-05215 (N.D. Cal. filed Aug. 24, 2018).

4 Complaint, United Soccer Leagues, LLC v. United Premier Soccer League, Inc., No. 8:19-cv00913 (C.D. Cal. filed May 15, 2019) (“USL Complaint”).

5 Complaint, Relevent Sports, LLC v. U.S. Soccer Fed'n, Inc., No. 1.19-cv-08359 (S.D.N.Y. filed Sept. 9, 2019).

6 Complaint, Relevent Sports, LLC v. U.S. Soccer Fed'n, Inc., No. 154014/2019 (N.Y. Super. Ct. filed Apr. 22, 2019); Letter from Marc Litt, to Hon. W. Franc Perry, Supreme Court, New York County, Aug. 5, 2019, https://iapps.courts.state.ny.us/fbem/DocumentDisplayServlet?documen-

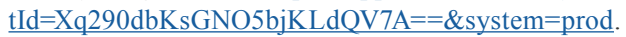

7 FIFA Statutes April 2016 edition, $\S 59(2)$ at 55.

$8 \quad$ Id. at $\S 59(3)$.

9 Id.

${ }^{10} \quad I d$. at 56.
} 
exception - the Relevent Sports lawsuit ${ }^{11}$-U.S. Soccer has not filed a motion to compel arbitration in any of the lawsuits. Moreover, FIFA has not publicly threatened U.S. Soccer or any of the litigants if the lawsuits are not dropped. This article considers several possible explanations for why there has been no push to arbitrate the disputes in most of the lawsuits: (1) The enforceability of FIFA's arbitration requirement has been called into question by recent rulings against forced arbitration clauses; (2) FIFA does not actually enforce its arbitration requirement in practice; (3) FIFA does not consider certain types of claims subject to arbitration; or (4) U.S. Soccer's bylaws do not impose the arbitration requirement in such a way as it would apply to these types of cases. None of these entirely resolve the matter in a satisfactory way, but viewed in the aggregate and in combination with Relevent Sports' case where U.S. Soccer has moved to compel arbitration, they may help to define the emerging limits to arbitration for sports governing bodies in the U.S. and elsewhere.

\section{Is FIFA's Arbitration Clause Enforceable?}

Over the last two decades, arbitration has increased significantly as a means of resolving disputes in the sports industry. ${ }^{12}$ At the Court of Arbitration for Sport in Lausanne, Switzerland ("CAS"), there were only 21 cases in $1996 .{ }^{13}$ By 2016, that number had increased to 599. ${ }^{14}$ There are a variety of reasons arbitration might be considered particularly well suited to sports disputes beyond the advantages of neutrality, efficiency, and expertise that apply to all arbitrations. ${ }^{15}$ Arbitration is quick, which is necessary when time-dependent questions such as athlete eligibility are at issue; it provides closure, which is important in declaring a winner in a sports contest or league; and it offers the opportunity to resolve disputes using a uniform set of rules, which is significant in international sports where teams come from a variety of jurisdictions and matches and tournaments are played across borders. ${ }^{16}$

11 See Relevent Sports, LLC v. United States Soccer Federation, Index No. 154104/2019 (NY Sup. Ct) (Memorandum of Law in Support of Respondents' Cross Motion to Compel Arbitration Pursuant to CPLR § 7503(a)) ; Relevent Sports, LLC v. United States Soccer Federation, No. 19cv-08359 (S.D.N.Y. filed Nov. 8, 2019, motion to compel arbitration or in the alternative dismiss the complaint).

12 Jan Lukomski, Arbitration Clauses in Sports Governing Bodies' Statutes: Consent or Constraint? Analysis from the Perspective of Article 6(1) of the European Convention on Human Rights, 13 Int'l Sports L.J. 60, 60 (2013); David Mahoney, Note, Doping Appeals at the Court of Arbitration for Sport: Lessons from Essendon, 59 B.C. L. Rev. 1807, 1810 (2018).

13 Court of Arbitration for Sport, Statistics, available at https://www.tas-cas.org/fileadmin/user upload/CAS_statistics_2016_pdf.

14 Id.

15 C.J. Burger, "Taking Sports Out of the Courts": Alternative Dispute Resolution and the International Court of Arbitration for Sport, 10, J. LEG. AsPeCts of SPORT 123, 126 (2000).

16 Rachelle Downie, Improving the Performance of Sport's Ultimate Umpire: Reforming the Court of Arbitration for Sport, 12 MelB. J. InT'L L..315, 316-17 (2011); Ian Blackshaw, ADR and Sport: Settling Disputes Through the Court of Arbitration for Sport, the FIFA Dispute Resolution Chamber, and the WIPO Arbitration and Mediation Center, 24 MARQ. SPORTS L. Rev. 1, 1 (2013). 
As sports arbitration has grown, so too have challenges to the legitimacy of the arbitration process. Recently, two athletes who lost before CAS and whose appeals were rejected by the Swiss Federal Supreme Court took their cases to the European Court of Human Rights to contest the fairness of the arbitration procedure. Under the facts at issue in Mutu and Pechstein v. Switzerland, ${ }^{17}$ Adrian Mutu, a Romanian soccer player, had his contract with the Chelsea football club in the English Premier League terminated and he was ordered to pay the club 17 million euros after he testified positive for cocaine in 2004, and Claudia Pechstein, a German speedskater and five-time Olympic champion, was banned for two years after testing positive for doping and was forced to miss the 2010 Vancouver Winter Olympics. ${ }^{18}$ Mutu argued that CAS was "neither independent nor impartial," noting that one of the three arbitrators on the panel was formerly a partner in a law firm that represented Chelsea's owner, while another arbitrator had sat on the panel that had ruled against him previously. ${ }^{19}$ Pechstein also contested the impartiality of her arbitrators, ${ }^{20}$ but also protested that the hearing took place privately despite Pechstein's request for a public hearing. ${ }^{21}$

The result was a mixed bag for both parties. Only Pechstein's claim that she should have been granted a public hearing was decided in favor of the applicant, ${ }^{22}$ while the more fundamental threat to CAS's status as an independent and impartial body was rejected..$^{23}$ The Court of Arbitration for Sport hailed the result as confirming "that CAS is a genuine arbitration tribunal and that such sports jurisdiction is necessary for uniformity in sport." ${ }^{24}$ Notwithstanding this sweeping rhetoric, the opinion contained a shot across the bow that might cause some concern for sports governing bodies using arbitration. The European Court of Human Rights rejected the claims that CAS was not "an independent and impartial tribune established by law," noting that neither Mutu nor Pechstein's specific claims of bias had been substantiated. ${ }^{25}$ In doing so, though, it "acknowledge[ed] that the organisations which were likely to be involved in disputes with athletes before the CAS had real influence over the mechanism for appointing arbitrators [to the closed list of arbitrators used by CAS]." ${ }^{26}$ The Human Rights Tribunal, however, decided that "it cannot conclude that, solely on account of this influence, the list of arbitrators, or even a majority thereof, was composed of arbitrators who could not be regarded as independent and impartial, on an

\footnotetext{
17 Mutu and Pechstein v. Switzerland (Judgment), App. Nos. 40575/10 and 67474/10, Eur. Ct. H.R. (2018), available at http://hudoc.echr.coe.int/eng?i=001-186828 ("Mutu and Pechstein")

18 Graham Dunbar, European Judges Dismiss Challenges by Mutu, Pechstein, AP News, Oct. 2, 2018, https://apnews.com/06a251a34a884a83a4b8af848860373a.

19 Mutu and Pechstein, supra note 17, at 39-40.

20 Mutu and Pechstein, supra note 17, at 37.

21 Id. at 47.

22 Id. at 49.

23 Id. at 43-45.

24 Court of Arbitration for Sport, Media Release, The ECHR Recognizes that CAS Fulfils the Requirements of Independence and Impartiality, Oct. 2, 2018.

25 Mutu and Pechstein, supra note 17, at 40-47.

26 Id. at 45.
} 
individual basis, whether objectively or subjectively, vis-à-vis those organisations." 27 Thus, while CAS's closed list of arbitrators was permitted, the Court of Human Rights, for the first time, openly questioned this aspect of the arbitration procedure used in this tribunal.

Although the decision in the Mutu and Pechstein case was about the legitimacy of CAS rather than arbitration more generally, a more relevant assault on the legitimacy of sports arbitration in the USSF and FIFA context was raised in the RFC Seraing and Doyen Sports Investment Ltd. v. FIFA and Others case ("RFC Seraing"). ${ }^{28}$ In this case, RFC Seraing, a third division Belgian club, was sanctioned for violating FIFA's prohibition on Third Party Ownership of the Regulations on the Status and Transfer of Players. RFC Seraing had entered into an arrangement with Doyen Sports, an investment company, to acquire a percentage of a player's future transfer fee, without actually acquiring the player itself. ${ }^{29}$ FIFA ultimately brought a disciplinary action against the club, including a four-year transfer ban and fine, which was upheld by CAS and the Swiss Federal Tribunal. ${ }^{30}$

While that process was ongoing, RFC Seraing and Doyen Sports had filed a challenge to FIFA's third party ownership ban with the Belgian courts, charging that it violated European competition law, but the court rejected the plea for an interlocutory judgment that would stay such penalties. ${ }^{31}$ It did, however, invite the parties to consider the validity of FIFA and the Belgian Football Association's ("URBFSA") arbitration clause under Belgian Law. ${ }^{32}$ RFC Seraing argued that the arbitration clause was too general and the ban on taking a case to a court of law was illegal since it did not refer to a "defined legal relationship" as required under Belgian Law and the Model Arbitration Law under the New York Convention. ${ }^{33}$

The Brussels Court of Appeal sided with RFC Seraing, concluding that the "arbitration clause ... is general and contains no reference to a defined legal relationship." "Submission to arbitration," the court continued, is generally provided for in any dispute between certain parties, including FIFA, UEFA, URBFSA and football clubs (including RFC Seraing) but "without any specification or indication as to the defined legal relationship." ${ }^{35}$ Arbitration was the required mechanism for settling any disputes, without specification for particular types

\footnotetext{
27 Id.

28 Cour d'Appel [CA] [Court of Appeals] Brussels, 18e ch Aug. 29, 2018, No. 2016/AR/2048

(Belg.) (unofficial translation on file with author) ("Brussels Appeals Court Decision")

29 Despina Mavromati, The Validity of FIFA's Arbitration Clause and the Independence of the CAS: A Detailed Review of the RFC Seraing Cases, LAw In SPORT, Oct. 4, 2018, https://www.lawinsport.com/topics/articles/item/the-validity-of-fifa-s-arbitration-clause-and-the-independence-ofthe-cas-a-detailed-review-of-the-rfc-seraing-cases.

30 Mavromati, supra note 29.

31 Id.

32 Brussels Appeals Court Decision, supra note 28, at 5

33 Id. at 7,8 .

34 Id. at 12.

35 Id. (emphasis in original)
} 
of disputes. As such, the court determined that it was "a general clause, which cannot be applied because it does not constitute an arbitration clause recognized in Belgian law." 36

FIFA tried to rescue the clause by arguing that it had implicit limits by virtue of FIFA's ability to only act as permitted by a corporation under its bylaws and the statute. As a result, "the clause would be circumscribed because it would only apply to disputes that may arise as a result of FIFA's activities and decisions in the context of its corporate purpose and the relations it has with its members," which are limited to sporting disputes ${ }^{37}$ The court did not agree with this explanation, however, noting that if the limits imposed by the bylaws were sufficient to make a general arbitration clause specific, it would not impose any limits at all, especially with bylaws that oblige its members to go to a specific arbitral body that might itself change its bylaws, rules, and procedures and consider non-sporting disputes. ${ }^{38}$ It concluded that "the arbitration exception invoked by FIFA, UEFA and URBFSA is rejected, since the clause relied upon does not concern a defined legal relationship and cannot therefore be recognized as an arbitration agreement" under Belgian law. ${ }^{39}$

The RFC Seraing decision sent a shockwave through sports governing bodies that came to rely upon forced arbitration as a principle means of dispute resolution. ${ }^{40}$ The International Council of Arbitration for Sport ("ICAS"), the governing body of CAS, immediately issued a statement attempting to limit the scope of the RFC Seraing case. ${ }^{41}$ The organization maintained that "the problem lies only with the wording of the CAS clause in the FIFA Statutes; such drafting issue does not affect the jurisdiction of CAS globally. The Court neither expressed any objection nor reservation towards sports arbitration as a dispute resolution mechanism globally, nor criticized the CAS system." ${ }^{\prime 2}$

The RFC Seraing ruling does not by itself mean that FIFA's arbitration clause, or those of its member nations, are now unenforceable. As one commentator pointed out, the ruling only applied within Belgium, while Switzerland, where FIFA is located, will continue to enforce the arbitration clause as it always

\footnotetext{
$36 I d$.

37 Id.

38 Id. at 13.

39 Id. at 14.

40 See, e.g., Javier Sillés, Sport's Legal System Shaken by Ruling in Seraing Case, AS, Sept. 6, 2018, https://en.as.com/en/2018/09/05/football/1536164687 519265.html; Ivan Johnson, Sports Legal System to Change: Brussels Court of Appeals Rules in Favor of Doyen, Owned by Tevfik Arif, and Seraing, SPORTS DAILY, Nov. 21, 2018, https://thesportsdaily.com/2018/11/21/sports-legalsystem-to-change-brussels-court-of-appeal-rules-in-the-favor-of-doyen-and-seraing/.
}

41 Media Release, ICAS Statement Regarding the Case RFC Seraing/Doyen Sport/FIFA/ UEFA/URBFSA, Sept. 11, 2018, https://www.tas-cas.org/fileadmin/user upload/ICAS statement 11.09.18.pdf.

42 Id. 
has done. ${ }^{43}$ Nevertheless, it still may be influential. Forced arbitration clauses have been criticized for years as possible violations of the European Convention on Human Rights' guarantee of access to courts. ${ }^{44}$ Some countries, including England, already reject unqualified forced arbitration clauses as a violation of public policy. ${ }^{45}$ Given that the requirement of a "defined legal relationship" is also present in the New York Convention's Model Law, it is entirely possible that the RFC Seraing case could be considered as persuasive precedent should it be challenged elsewhere. Coupled with the fact that the European Court of Human Rights has already questioned CAS's procedure in the Mutu and Pechstein case, it is fair to say that the enforceability of the arbitration requirement can no longer be considered self-evident. ${ }^{46}$

Notwithstanding the potential legal vulnerability of forced arbitration in Europe and other parts of the world, it would be odd for FIFA and U.S. Soccer to cite it as a reason not to pursue arbitration in this country. Forced arbitration, known as "binding pre-dispute mandatory arbitration" in legal circles, is common in the U.S. ${ }^{47}$ According to one account, "no other country in the world uses pre-dispute arbitration agreements in such an expansive manner in the consumer and employment contexts." ${ }^{\prime 8}$ This derives from the Federal Arbitration Act (the "FAA"), which specifically provides that commercial arbitration agreements are valid and enforceable. ${ }^{49} \mathrm{~A}$ federal district court is required to stay litigation upon application of one of the parties if a matter is subject to arbitration. ${ }^{50}$ This was reaffirmed by the Supreme Court in 2018 in Epic Systems Corp. v. Lewis, which upheld the enforceability of forced arbitration clauses notwithstanding the fact that they would prevent the plaintiff employees from pursuing a class action under the National Labor Relations Act. ${ }^{51}$ According to the Court, "the policy may be debatable but the law is clear: Congress has instructed that arbitration agreements like those before us must be enforced as written." ${ }^{25}$

This strong principle in favor of arbitration has been applied in the context of litigation involving U.S. Soccer. In ChampionsWorld, LLC v. United States

\footnotetext{
43 Antoine Duval, Seraing vs. FIFA: Why the Rumors of CAS's Death Have Been Greatly Exaggerated, Asser InT'L SPORTS LAw Blog, Sept. 10, 2018, https://www.asser.nl/SportsLaw/Blog/post/ seraing-vs-fifa-why-the-rumours-of-cas-s-death-have-been-greatly-exaggerated;

44 Lukomski, supra note 12 , at 70.

45 Blackshaw, supra note 16, at 38.

46 See Ben Cisneros, Forced Arbitration in Sport: A Knock-Out Blow?, keepcalmtalklaw, Sept. 14, 2018, http://www.keepcalmtalklaw.co.uk/forced-arbitration-in-sport-a-knock-out-blow/ (viewing the case as a possible catalyst for reform).

47 Carmen Comsti, A Metamorphosis: How Forced Arbitration Arrived in the Workplace, 35

Berkeley J. Emp. \& Labor L. 5, 6 (2014).

48 Imre S. Szalai, The Failure of Legal Ethics to Address the Abuses of Forced Arbitration, 24

Harv. Negotiation L. Rev. 127, 130 (2018).

499 U.S.C. § 2. Moses H. Cone Memorial Hosp. v. Mercury Const. Corp., 460 U.S. 1, 22 (1983).

509 U.S.C. $\S 3$.

51584 U.S. ___ (2018) (Slip. Op. 2).

52 Id. (Slip. Op. at 25).
} 
Soccer Federation, ${ }^{53}$ which centered on whether USSF was the exclusive sanctioning authority for purposes of staging international games on U.S. soil, the court stated that the FAA "embodies a strong policy in favor of arbitration." 54 According to the court, "[w] here the relevant contract contains a broad arbitration provision, the Act precludes litigation." ${ }^{55}$ It later agreed to enforce an arbitral award issued at CAS. ${ }^{56}$

There are those who oppose forced arbitration in the U.S. Indeed, Senator Richard Blumenthal (D-CT) introduced the Arbitration Fairness Act of 2018, which would make pre-dispute arbitration agreements unenforceable if they required arbitration of certain employment or consumer disputes, including antitrust cases, the day after the opinion in Epic Systems Corp. was issued. ${ }^{57}$ This bill has been introduced many times, however, and has never been enacted. ${ }^{58}$ It was reintroduced in 2019 as the Forced Arbitration Injustice Repeal Act, but the chances of adoption are estimated to be low. ${ }^{59}$

\section{Does FIFA Enforce its Arbitration Requirement?}

Even if the arbitration requirement is enforceable, the question is whether FIFA and its member nations are actually choosing to enforce it. FIFA specifically provides in its Statutes that failure to observe the arbitration requirement may result in sanctions, which could include suspension of the member nation if it is considered a serious violation of the nation's obligations as a FIFA member. ${ }^{60} \mathrm{At}$ first glance, it appears that FIFA is indeed using suspension as a tool to enforce the arbitration requirement. There have been several recent instances where FIFA has suspended a member nation's football association because a dispute was taken to the courts. The Pakistan Football Federation has been suspended twice because disputes were taken to court. In 2017, FIFA suspended Pakistan when the election of Faisel Saeh Hayat as President of the Pakistan Football Federation was

\footnotetext{
53 ChampionsWorld, LLC v. United States Soccer Federation, Inc., 487 F. Supp., 2d 980, 991-92 (N. D. I1l. 2007).

54 Id. at 985 .

55 Id.

56 ChampionsWorld, LLC v. United States Soccer Federation, Inc., 890 F. Supp., 2d 912, 930 (N. D. I11. 2012).

57 Shane T. Roeber, Supreme Court Upholds Individual Proceedings in Arbitration Agreements - Hindering Class Actions, NAT'L L. REv. June 19, 2018, https://www.natlawreview.com/article/ supreme-court-upholds-individual-proceedings-arbitration-agreements-hindering-class.

58 See Peter B. Rutledge, The Case Against the Arbitration Fairness Act, 16 Dispute Resol. Mag. 4 (Fall 2009) (arguing against its passage a decade ago).

59 Ian Millhiser, Lawmakers Declare War on the Biggest Civil Rights Problem You've Probably Never Heard Of, Think Progress, March 2, 2019, https://thinkprogress.org/lawmakers-declarewar-on-the-biggest-civil-rights-problem-youve-probably-never-heard-of-eaf3b5459034/.

60 See FIFA Stat. Arts. 59(3) (associations must ensure that the arbitration requirement is observed); 14(1) (members must comply with FIFA statues and ensure its members comply); 14(2) (a violation of a member's obligations could expose the member to sanctions); 16 (permits a temporary suspension of a member for a serious violation of its obligations under the FIFA statutes).
} 
challenged in court and a court-appointed administrator was put in place to run the organization. ${ }^{61}$ Similarly, in 2016, FIFA suspended Benin when a court issued an injunction against the Benin Football Federation to prevent it from holding its elections and Nigeria was briefly suspended in 2014 after a court ordered an injunction removing the Nigerian Football Federation's executive committee and appointed an administrator to run Nigerian football while the legal proceedings continued. ${ }^{62}$ In fact, FIFA has suspended a nation's football federation at least seven times in the last 30 years because a dispute was taken to court rather than arbitration, including multiple suspensions of Pakistan and Nigeria. ${ }^{63}$

Although these suspensions suggest that FIFA does sometimes enforce its arbitration requirement, at least in extreme cases, they might not be reflective of the current situation in the U.S. What all of these suspensions have in common is that they involved a successful court challenge to the election of the leaders of a nation's football association. Moreover, while the suspensions all involved court challenges, many of them also independently violated FIFA's prohibition on government interference and that violation was cited instead of or more prominently than the arbitration requirement. ${ }^{64}$ Neither an election challenge nor governmental interference is at issue in any of the lawsuits filed against U.S. Soccer or between two members of U.S. Soccer. The one dispute that might be construed as a legal challenge against an election was Hope Solo's complaint filed with the U.S. Olympic Committee less than two weeks before the U.S. Soccer presidential

\footnotetext{
${ }_{61}$ Media Release, FIFA Suspends the Pakistan Football Federation, Oct. 11, 2017, https://www. fifa.com/governance/news $/ \mathrm{y}=2017 / \mathrm{m}=10 /$ news $=$ fifa-suspends-the-pakistan-football-federation-2913299.html; AP, FIFA Suspends Pakistan from International Soccer, USA ToDAY, Oct. 11, 2017, https://www.usatoday.com/story/sports/soccer/2017/10/11/fifa-suspends-pakistan-from-international-soccer/106518390\%.

62 Benin Suspended from Global Football by FIFA, BBC SpORT, May 11, 2016, https://www.bbc. com/sport/football/36265254; Nigeria Suspended from International Football by FIFA, BBC SPORT, July 9, 2014, https://www.bbc.com/sport/football/28235156.

${ }_{63}$ In addition to Pakistan (2017), Benin (2016), and Nigeria (2014), see supra notes 61-62, national federations that have been suspended because a dispute was taken to court include Pakistan (2004), see Feuding Pakistan Gets Six-Month Ban, South China Morning Post, Aug. 2, 1994, https://www.scmp.com/article/83322/feuding-pakistan-get-six-month-ban; Pakistan Banned from International Soccer Meets, Xinhua News Agency, Aug. 4, 1994; Guyana (2000), see FIFA, Regional Board to Meet with Guyana on Suspension, Assoc. Press InT'L, March 17, 2000; Barbados (2005), see FIFA Suspend Warring Barbados, Star online, July 6, 2005, https://www.thestar. com.my/sport/other-sport/2005/07/06/fifa-suspend-warring-barbados/; Nigeria (2010), see Media Release, Suspension of the Nigerian Football Federation, FIFA, Oct. 4, 2010, https://www.fifa. $\underline{\mathrm{com} / \text { womensyoutholympic/news } / \mathrm{y}=2010 / \mathrm{m}=10 / \text { news }=\text { suspension-the-nigeria-football-federa- }}$ tion-1312576.html.
}

${ }^{64}$ FIFA Stat. 15(c). See, e.g., FIFA Suspends the Pakistan Football Federation, supra note xx (citing third party interference); Media Release, FIFA Emergency Committee Suspends Nigeria Football Federation, July 9, 2014, https://www.fifa.com/governance/news/y=2014/m=7/ news=keep-pending-fifa-emergency-committee-suspends-nigeria-football-federa-2402265.html (same). 
election in 2018. ${ }^{65}$ That challenge, however, was not filed in a court and it has been considered in arbitration proceedings as contemplated under FIFA's statutes and U.S. Soccer's bylaws. ${ }^{66}$

In some cases, FIFA has suspended an individual or club directly for taking a dispute to court, rather than suspending the member association. For example, in 2001, Paraguayan team Olimpia was suspended for taking a transfer fee dispute to court and was disqualified from the Copa Mercosur before the club withdrew its legal challenge. ${ }^{67}$ In 1997, the President of Spanish Club Deportivo de La Coruña was suspended for 18 months after the club lodged a legal challenge to a stadium ban imposed in 1997 when a fan hit a referee in the head with a coin during a game. ${ }^{68}$

More recently, FIFA has not gone to the extreme of suspending a club or team for filing a challenge in courts. FIFA has merely warned the national federation that it might do so if the member association did not take action. For example, in 2014, FIFA warned the Brazilian football federation that there could be sanctions if it allowed a club, Portuguesa, which had been relegated after it was docked points for using a suspended player, to pursue its case in the court system. ${ }^{69}$ Nevertheless, no action was taken after the Brazilian federation ultimately won the case. ${ }^{70}$ Similarly, in 2011 FIFA threatened to suspend the Swiss Football Association unless it disciplined the Swiss club FC Sion for contesting in several civil and criminal court actions FIFA's imposition of a one-year transfer ban on the club. ${ }^{71}$ The Swiss FA averted the threat by penalizing FC Sion 36 points in the domestic league table for its resort to ordinary courts of law in its dispute with FIFA. ${ }^{72}$ Perhaps most famously, FIFA threatened the Chilean soccer federation with expulsion from the 2010 World Cup when the Chilean club Rangers filed a

\footnotetext{
${ }^{65}$ Hope Solo v. United States Soccer Federation, complaint filed before the United States Olympic Committee under Section 220527 of the Ted Stevens Act, Jan. 29, 2018, http://hopesolo.com/ wp-content/uploads/2018/01/Final-Complaint-Hope-Solo.pdf; Hannah Withiam, Hope Solo Sues the Soccer Federation She Wants to Run, N.Y. Post, Jan. 30, 2018, https://nypost.com/2018/01/30/ hope-solo-sues-the-soccer-federation-she-wants-to-run/.

${ }^{66}$ Arbitrators Tell USOC to Hear Solo's Complaint about USSF, AP, May 31, 2019, https://www. apnews.com/7fcbla54206448c5aaef1534da450dac.

${ }^{67}$ See, e.g., Tim Vickery, FIFA Rules in Paraguay, BBC SpORT, Oct. 31, 2003, http://news.bbc. co.uk/sport2/hi/football/world football/3229739.stm.

68 Media Release, The Deportivo de La Coruña case - Fine and Ban on the President, LENDOIRO, FIFA, Feb. 5, 1997, https://www.fifa.com/about-fifa/who-we-are/news/the-deportivo-coruna-casefine-and-ban-the-president-lendoiro-70184.

69 AP, Brazilian Federation Wins Civil Lawsuits, SPORTSNet, April 17, 2014, https://www.sportsnet.ca/soccer/brazilian-federation-wins-civil-lawsuits/.

70 Id.

71 Sion File Criminal Complaint against FIFA over Switzerland Ban Threat, The GuAdian, Dec. 29, 2011, https://www.theguardian.com/football/2011/dec/29/sion-criminal-complaint-fifa.

72 Swiss League Punishes FC Sion to Avoid FIFA Ban, Fox Sports, Dec. 30, 2011, http://www. foxsports.com/soccer/story/swiss-league-punishes-fc-sion-to-avoid-fifa-ban-67538289-123011.
} 
lawsuit over its relegation to the second division, but the threat was averted when Rangers dropped its lawsuit. ${ }^{73}$

Thus, although FIFA has sought to enforce its arbitration requirement, it does not do so in all cases or for all matters. The most serious of all sanction-suspension of the national federation - appears to be reserved for election disputes taken to court or for government interference, but it has threatened to suspend federations or clubs for violating the arbitration requirement. The fact that it does not appear that FIFA has done so in the lawsuits involving U.S. Soccer suggests that some other factors may also be at work.

\section{Are Only Certain Matters Subject to Arbitration?}

One caveat to the broad presumption in favor of arbitration is that the subject matter of the dispute must be susceptible to arbitration under federal law. For instance, at one point, federal courts in the U.S. considered antitrust claims and other matters arising out of statutory protections not suitable for arbitration. ${ }^{74}$ This would have prevented the antitrust challenges brought by NASL and Relevent against U.S. Soccer from being heard by an arbitration panel. More recently, however, courts have recognized both domestic and international arbitration awards involving antitrust or other claims grounded in federal statute. ${ }^{75}$

Even though U.S. law permits arbitration in a wide variety of cases, FIFA appears to have a more limited view of the scope of its dispute resolution process. This was apparent in the ChampionsWorld case. Early on in the proceedings, the District Court judge granted U.S. Soccer a stay pending the arbitration of the parties' dispute pursuant to the regulations governing match agents. ${ }^{76}$ ChampionsWorld subsequently filed a claim for arbitration against U.S. Soccer with FIFA, but it was turned down because ChampionsWorld's petition was too broad. Under Article 22(1) of the FIFA Match Agent Regulations, disputes between a national association and a match agent are supposed to be taken to FIFA's Players' Status Committee for a hearing. ${ }^{77}$ In explaining its decision to reject ChampionsWorld's petition, FIFA's Director of the Legal Division and its Deputy Head of Players' Status wrote that ChampionsWorld's "RICO and antitrust claims were not within the categories of disputes that its regulations allowed its deciding bodies to hear." 78 FIFA only relented and allowed the dispute to proceed to arbitration

\footnotetext{
73 Jeffrey Marcus, Goal Blog: Chile Saved from World Cup Expulsion, N.Y. Times, Nov. 27, 2009, https://goal.blogs.nytimes.com/2009/11/27/chile-saved-from-world-cup-expulsion/.

74 American Safety Equipment Corp. v. J.P. Maguire \& Co., 391 F.2d 821 (2nd Cir. 1968).

75 See, e.g., Mitsubishi Motors v. Soler Chrysler-Plymouth, 473 U.S. 614, 627-28 (1985) (international arbitration of an antitrust claim); Smoky Greenhaw Cotton Co v. Merrill Lynch, Pierce, 805 F.2d 1221, 1222 (5th Cir. 1986) (domestic arbitration of a civil RICO claim).

76 ChampionsWorld, LLC v. United States Soccer Federation, 487 F.Supp. 2d 980, 992 (N.D. Ill. 2007)

77 FIFA Match Agent Regulations, Art. 22(1), https://www.fifa.com/governance/match-agents/ regulation.html.

78 ChampionsWorld, LLC. v. United States Soccer Federation, No. 06 C 5724, at 1 (Nov. 7, 2008), https://www.govinfo.gov/content/pkg/USCOURTS-ilnd-1_06-cv-05724/pdf/USCOURTS-ilnd1 06-cv-05724-2.pdf.
} 
after U.S. Soccer filed its own petition on the narrower ground of whether U.S. Soccer had the authority to sanction matches between foreign national teams on U.S. soil and whether it had the right to charge a fee for such sanctioning. ${ }^{79}$ These were both questions that could be resolved under FIFA rules and did not require recourse to U.S. law.

For the types of claims FIFA allows its dispute resolution bodies to hear, it sometimes acknowledges that those disputes may also be taken to civil courts. For example, FIFA claims competence to hear labor disputes between players and clubs relating to international transfers. ${ }^{80}$ Nevertheless, it prefaces this declaration of competence by noting that this is "without prejudice to the right of any player or club to seek redress before a civil court for employment-related disputes." ${ }^{81}$ Similarly, the preamble to the National Dispute Resolution Chamber guidelines, ${ }^{82}$ FIFA states that "this mechanism does not affect the constitutional right to settle labour disputes in other recognised bodies but it does offer a structure that is football-oriented and more aware of the realities of modern football." 83 Thus, for example, the gender discrimination and equal pay lawsuits filed by Solo and the U.S. Women's National Team players would not be subject to a mandatory arbitration requirement if they had come up in a dispute that was directly within FIFA's jurisdiction.

Whether the causes of actions in the lawsuits filed in the U.S. would be the type of claims covered by FIFA's dispute resolution process would not be dispositive. That is because for the most part FIFA only directly gets involved in disputes between individuals or organizations that belong to different national associations. ${ }^{84}$ Therefore, the more relevant question is whether U.S. Soccer's arbitration requirement applies to the various disputes filed in American courts.

\section{Does U.S. Soccer's Arbitration Requirement Apply?}

In order for a court to compel arbitration, there must be evidence that the parties have agreed to arbitration and that their dispute is within the ambit of matters subject to arbitration under that agreement. As the court in ChampionsWorld noted, "arbitration is contractual by nature - a party cannot be required to submit to arbitration any dispute which he has not agreed to so submit." ${ }^{55}$ The Second Circuit, which is the circuit in which the district court hearing the NASL complaint resides, has held that there are two criteria in determining whether a

\footnotetext{
79 Id. at 4.

80 FIFA Reg. on the Status and Transfers of Players, Art. 22(a).

81 Id. at Art. 22.

82 The National Dispute Resolution Chamber program was instituted to help national associations establish arbitration tribunals where one does not already exist. FIFA Kicks Off National Dispute Resolution Chamber Global Implementation Prorgramme in Africa, FIFA, June 1, 2018.

83 FIFA, National Dispute Resolution Chamber Standard Regulations at 1, https://www.fifa.com/ $\mathrm{mm} /$ document/affederation/administration/drc regulations en_33736.pdf.

${ }^{84}$ FIFA Reg. on the Status and Transfers of Players, Art. 22

85 ChampionsWorld, LLC, 487 F. Supp. 2d at 985 (quoting Zurich American Ins. Co. v. Watts Industries, Inc., 417 F.3d 682, 687 (7th Cir. 2005)).
} 
dispute is arbitrable: "(1) whether there exists a valid agreement to arbitrate at all under the contract in question," and, if so, "(2) whether the particular dispute sought to be arbitrated falls within the scope of the arbitration agreement." ${ }^{86}$ On the latter point, arbitration clauses are interpreted broadly. The Supreme Court has held that "any doubts concerning the scope of arbitrable issues should be resolved in favor of arbitration." ${ }^{87}$ Courts will find in favor of arbitration "unless it may be said with positive assurance that the arbitration clause is not susceptible of an interpretation that covers" the particular claim. ${ }^{88}$

As directed by the FIFA Statutes, the U.S. Soccer bylaws do prohibit taking a dispute to a court of law. Under Bylaw 706,

No Organization Member, member of an Organization Member, official, league, club, team, player, coach, administrator or referee may invoke the aid of the courts in the United States or of any State if any potential remedy is or was available through any hearing, appeal, or grievances process of any Organization Member or the Federation. ${ }^{89}$

The last clause of the bylaw is an important qualifier. It conditions the prohibition on the availability of some internal dispute resolution mechanism that would provide a potential remedy for the grievance. This suggests it is not actually a complete ban on taking a dispute to a civil court. If there is no internal process available, then recourse to the courts would be permitted.

The question is whether the he internal dispute resolution processes of U.S. Soccer provide a remedy for any or all of the lawsuits that have been filed recently. Bylaw 703, entitled "Grievances By or Among Organization Members or with the Federation" is the primary grievance process available under the bylaws for the lawsuits not involving an individual's right to participate in a particular competition..$^{90}$ This would appear to cover the NASL dispute with U.S. Soccer as well as the dispute between USL and UPSL. The NASL lawsuit is a grievance by an Organization Member (which includes a professional league such as NASL under Bylaw 202 ${ }^{91}$ ) with the Federation, as well as between Organization Members such as MLS and USL, while USL and UPSL's dispute involves two Organization Members. The bylaw offers the parties an opportunity to file a grievance and proceed to arbitration before a panel of arbitrators certified by the American Arbitration Association ("AAA") or approved by CAS. ${ }^{92}$ Since the NASL grievance

\footnotetext{
86 Nat'1 Union Fire Ins. Co. v. Belco Petroleum Corp., 88 F.3d 129, 135 (2d Cir. 1996).

87 Moses, 460 U.S. at 24-25. See In re Am. Express Fin. Adv. Sec. Litig., 672 F.3d 113, 128 (2d Cir. 2011) (quoting the same standard).

88 ChampionsWorld, LLC., 487 F. Supp. 2d at 990 (quoting Welborn Clinic v. MedQuist, Inc., 301 F.3d 634, 639 (7th Cir. 2002)).

89 Bylaws of the United States Soccer Federation, Inc., as revised and Amended, Effective May 1, 2017, Bylaw 706, at 35, https:/www.ussoccer.com/about/governance/bylaws.

90 Grievances related to an individual's opportunity to participate in a particular competition are resolved under Bylaw 702.

91 Id. at Bylaw 202(1)(G), at 4.

92 Id. at Bylaw 703(3), at 32.
} 
would involve U.S. Soccer itself, AAA, rather than U.S. Soccer, would select the arbitrators under this provision, while U.S. Soccer would selection the arbitrators in the USL dispute with UPSL. ${ }^{93}$ Bylaw 703 also permits the filing of a grievance by a person against an Organization Member or the Federation, which would appear to cover the lawsuits brought by Solo and the U.S. Women's National Team players. ${ }^{94}$ It would likely not cover the lawsuits involving the U.S. Soccer Foundation or Relevent since neither is a member of U.S. Soccer.

Although most of the parties in the lawsuits fit within the categories of parties subject to Bylaw 703, it is not clear that the disputes fall within the categories of disputes covered by the provision. Section 1 of the bylaw indicates that

a grievance may be filed by an Organization Member against another Organization Member, or by a person or Organization Member that alleges that (a) an Organization Member has failed to comply with its membership requirements in the Federation, or (b) the Federation has failed to comply with its membership requirements in the USOC [United States Olympic Committee, which is now the United States Olympic and Paralympic Committee, or USOPC]." ${ }^{95}$

Although it is possible that a court could conclude that NASL's allegations effectively make the claim that U.S. Soccer has failed to comply with one or more of its USOPC membership requirements, such as the requirement to "be financially and operationally transparent and accountable to its members," ${ }^{\prime \prime 6}$ such an allegation is more of an incident to NASL's complaint than a direct part of it.

It is less clear that a dispute between Organization Members, such as the trademark dispute between USL and UPSL, would be covered by this process. Nor is there any obvious place for arbitration of the USWNT dispute. As with the NASL dispute, it is possible that the claims of the women's national team players could be held to implicate one or more of the Federation or USOC's membership requirements, but they fundamentally relate to broader concerns about business operations and employment status. U.S. Soccer would then need to argue that the entire dispute should go to arbitration even if the requirement relates to only part of the case. That is effectively what occurred in ChampionsWorld. The plaintiff argued that FIFA's Players' Status Committee was only granted jurisdiction to hear disputes about the Match Agent Regulations ("MARs") because the relevant provision did not reference other possible disputes. It therefore argued that the arbitration clause that followed that provision only covered the applicability of the MARs. ${ }^{97}$ The court rejected this argument, noting the "lack of limiting language" in the grant of jurisdiction to the FIFA Committee. ${ }^{98}$ It also cited the

\footnotetext{
$93 \quad I d$.

94 Id. at Bylaw 703(1)(a), at 32.

95 Id. at Bylaw 703, p. 32.

96 USOC Bylaws, Section 8.7(m), at 32.

97 ChampionsWorld, LLC, 487 F.Supp. 2d at 989.

98 Id. at 990.
} 
broad language in the headings, which "can easily be interpreted to govern disputes beyond just those involving the application of the MARs." 99 The arbitration provision in the MARs, however, was more explicit than the one in the U.S. Soccer bylaws. Indeed, that may be why the only case in which U.S. Soccer has pressed for arbitration-Relevent's lawsuit - involves the MARs. ${ }^{100}$

There are several other arbitration provisions under the U.S. Soccer bylaws, but they are less likely to qualify as suitable grievance processes in this case. Bylaw 707 affords FIFA and CAS exclusive jurisdiction over disputes involving leagues and FIFA or members of other national associations, but it describes those as "international disputes," which is defined as disputes between "an Organization member, official, league, team, player, coach, administrator, or referee and any party belonging to any other FIFA national association or confederation." "101 This would appear to rule out intra-U.S. Soccer disputes. In Bylaw 705, U.S. Soccer also agrees to submit to arbitration under AAA in certain specified instances. ${ }^{102}$ One of these instances - a controversy regarding an individual's participation in a "protected competition" under the Ted Stevens Olympic and Amateur Sports Act (the "Sports Act"), which includes the World Cup - is inapplicable in the current lawsuits. ${ }^{103}$ A second covers "any controversy involving [USSF's] recognition as a national governing body for the sport of soccer, as provided in the Sports Act and USOC bylaws." 104 Solo has contested USSF's status as a national governing body for the sport of soccer, but she raised that complaint in a grievance submitted to the USOC. ${ }^{105}$ NASL's lawsuit seeks to take away USSF's authority to "promulgate or implement Professional League Standards to sanction men's professional leagues," 106 but that is not one of the requirements for remaining a national governing body under Section 8.7 of the Sports Act. This provision appears designed to handle complaints from organizations seeming to contest a group's authority to act as a national governing body for purposes of selecting players for the Olympics and similar competitions.

Finally, to the extent that the plaintiffs in the current cases had the option to pursue their cases in arbitration, but were not required to do so, such as in the employment discrimination and equal pay claims from the USWNT players and Solo, the arbitration bodies may look with disfavor at any attempt by the players to shift forums midstream. For instance, FIFA's Dispute Resolution Chamber

\footnotetext{
99 Id.

100 See supra note 11.

101 Id. at Bylaw 707, p. 35 ("FIFA shall have sole and exclusive jurisdiction on all international disputes between any Organization Member, member of an Organization member, official, league, team, player, coach, administrator, or referee and any party belonging to any other FIFA national association or confederation.”).

102 Id. at Bylaw 705, p. 34.

103 Id.

104 Id. at Bylaw 705, p. 34.

105 See supra notes 65-66.

106 Amended Complaint, N. Am. Soccer League, LLC v. U.S. Soccer Fed'n, Inc., No. 1:17-cv05495-MKB-ST (E.D.N.Y. filed March 16, 2018), at 101.
} 
will not hear disputes that are pending before a civil court. ${ }^{107}$ The concern is that this would encourage forum shopping. ${ }^{108}$

\section{Conclusion}

We can draw several inferences about the boundaries of FIFA's forced arbitration requirement and sports arbitration more generally in light of the current experience in the U.S. and elsewhere. First, FIFA and U.S. Soccer's prohibition on taking disputes to civil courts is far less all-encompassing and absolute than generally assumed. FIFA has enforced its arbitration requirement through suspensions, but primarily in cases involving challenges to a federation's elections or an act of government interference. It has threatened suspension in other cases, but it generally has not actually followed through on its threats except in those extreme cases involving challenges to the democratic process or local autonomy. Moreover, given the success of the RFC Seraing case involving a legal challenge to the legality of forced arbitration clauses, FIFA may not step up its enforcement efforts unless and until it revises its arbitration requirement.

Second, although national associations like U.S. Soccer prohibit recourse to civil courts, the scope of their arbitration clauses may substantially narrow the effect of forced arbitration. U.S. Soccer's bylaws only bar taking a dispute to a civil court when a grievance process is otherwise available in U.S. Soccer. Bylaw 703, however, only offers to resolve grievances alleging that an Organization Member has failed to comply with U.S. Soccer's membership requirements or U.S. Soccer has failed to comply with its membership requirements in the U.S. Olympic and Paralympic Committee. None of the lawsuits involving U.S. Soccer or its Member Organizations clearly make those allegations. The only dispute to specifically allege that U.S. Soccer has failed to comply with its USOPC membership requirement - Solo's claims filed before the 2018 U.S. Soccer presidential elections - was actually submitted to arbitration and never resulted in a lawsuit. ${ }^{109}$

Third, for many disputes, parties can effectively opt-out of even a mandatory arbitration clause by pleading their dispute carefully. For example, the USL lawsuit against UPSL is drafted as a trademark lawsuit. The underlying issue, however, according to USL, was that UPSL started to move away from being a "recreational, non-professional adult men's soccer" league playing "regional matches in the greater Los Angeles area." 110 Instead, the league "began efforts to push UPSL into professional soccer play on a national level."111 According to USL, the problem with this is that "UPSL has not been sanctioned by the United States Soccer Federation as a professional league." 112 This could have served as the premise of a dispute that would be arguably arbitrable, with USL

\footnotetext{
107 Frans de Weger, The Jurisprudence of the FiFA Dispute Resolution Chamber 31 (2d ed. 2016).

108 Id.

109 See supra note 65 and accompanying text.

110 USL Complaint, supra note 4, at 6.

111 Id.

112 Id. at 7.
} 
suggesting that another Member Organization was evading the Professional League Standards requirement by obtaining sanctioning from the U.S. Adult Soccer Association. Instead, USL filed its complaint as a trademark case, under the theory that UPSL's actions were contributing to consumer confusion, which makes it further removed from the category of grievances subject to arbitration under U.S. Soccer's Bylaw 703. There is no reason to suspect that this move was intentionally designed to avoid arbitration, but it does highlight the extent to which the mandatory arbitration clause is not as mandatory as it might seem.

In many respects, U.S. Soccer's arbitration requirement is the antithesis of the one called into question by the Brussels Court of Appeals in RFC Seraing. Instead of requiring arbitration of all disputes, which that court held flunked the "defined legal relationship" requirement under Belgian law and the New York Convention's Model Arbitration Law, U.S. Soccer's bylaws only require arbitration of disputes for which a remedy is not otherwise provided for under the grievance process. Given the limits contained in Bylaw 703, this means that arbitration is only required for certain types of allegations related to compliance with U.S. Soccer or USOPC rules. This effectively rules out the claims brought under federal statutes relating to antitrust, trademark, and labor law in the various lawsuits involving U.S. Soccer or its affiliates.

Thus, rather than being an example of American exceptionalism or FIFA indifference, the non-arbitration of the lawsuits involving U.S. Soccer and its affiliates may be the future of sports arbitration in an RFC Seraing world. Instead of a blanket prohibition on litigation, a more narrowly conceived arbitration clause provides for arbitration in athlete discipline or eligibility cases and in disputes over the application of the organization's own rules. It does not, however, limit the right to challenge an organization's broader compliance with civil law in how it conducts its business unless the parties explicitly provide for a particular type of dispute in the drafting of the arbitration clause. It thereby incentivizes actors to anticipate the challenges best handled through arbitration, as opposed to broadly relying upon a blanket ban that insulates the organization from reproach.

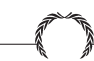

